\title{
Inequalities in middle-income Europe and Central Asia: A tale of three studies ${ }^{\text {th }}$
}

\author{
Ben Slay*, Tahmina Anvarova \\ United Nations Development Programme, \\ Regional Bureau for Europe and the Commonwealth of Independent States, New York, USA
}

\begin{abstract}
This paper focuses on how questions of inequalities in middle-income countries in Europe and Central Asia are dealt with in three recent studies: the EBRD's "Transition Report 2016-17"; the World Bank's 2018 study "Toward a new social contract: Taking on distributional tensions in Europe and Central Asia"; and UNDP's "Regional human development report 2016. Progress at risk: Inequalities and human development in Eastern Europe, Turkey, and Central Asia." While the three studies differ in terms of objectives, conceptual frameworks, country coverage, data and indicators, and policy recommendations, they also share important commonalities - particularly in terms of creating "regional" inequality narratives for transition economies, reconciling official data with common perceptions of inequalities in the region; improving data quality, quantity and availability, and changes in tax and social policies.
\end{abstract}

Keywords: inequality, economic transition, economic development, sustainable development, tax policy, tax reform, social policy, social protection, social contract, middle-income countries, Eastern Europe, Turkey, Central Asia.

JEL classification: H55, I32, P29, P31, P36, Z13.

\section{Introduction: Background}

Concerns about inequalities are growing globally, as observers in many developed and developing economies increasingly believe they undermine prospects for sustainable development through a multitude of channels. In developed economies, these concerns are apparent inter alia in the works of Piketty (2014), Stiglitz (2012), Milanovic (2011, 2016), and the OECD (2015), which focus on the distributional impact of capital accumulation/GDP growth dynamics,

\footnotetext{
This paper does not constitute an official statement of the views of UNDP, the United Nations, or its Member States.

* Corresponding author, E-mail address: ben.slay@undp.org
} 
financial globalization, structural and demographic changes, wage premia for skilled labor, and interest group articulation patterns. UNDP's Humanity Divided (UNDP, 2013) investigated causes and implications of inequalities in developing countries. It found that, while income inequalities are generally high and rising in many developing economies, some had managed to reduce them by expanding social safety nets and promoting the formalization of employment.

These narratives and experiences are not irrelevant for the transition economies of Europe and Central Asia. However, they miss some important elements of the challenges posed by inequalities for these countries. For one thing, despite their "developing"/middle-income country status, during socialism (prior to the 1990s) these economies reported relatively low socio-economic inequalities. While official data indicate that income inequalities rose during the "transition recessions" of the 1990s, these increases were interpreted by at least some observers as desirable (or at least inevitable) "corrections" of/ responses to often violent pre-transition social leveling. ${ }^{1}$ Moreover, official data (as shown both on national statistical office websites and in leading international databases like POVCALNET and SWIID) also indicate that, since 2000 , income inequalities in many of the countries have fallen back towards pre-transition levels. These data also indicate that falling inequalities helped reduce income poverty and allowed the region's middle classes (measured in income terms) to stage a comeback. They also suggest that relatively well developed social protection systems ${ }^{2}$ and comparatively high levels of gender equality $^{3}$ have ensured that the benefits of economic growth have been fairly evenly spread.

However, a closer look at official income inequality data may suggest less optimistic conclusions. For one thing, the official data may significantly understate actual levels of income inequalities in the region: household budget survey data are well known to suffer from errors of exclusion regarding the incomes of the very rich and the very poor. Moreover, the absence of credible, internationally comparable data on personal wealth often precludes evidence-based discussions about inequalities in the distribution of wealth - which, for a region whose political economy has often been described as dominated by "oligarchs" (Guriev and Rachinsky, 2005; Braguinsky, 2007), may be a conspicuous shortcoming. Official data do however indicate that large numbers of people are excluded from the "decent jobs" that provide middle-class salaries and access to social protection; women, labor migrants, the displaced, people with disabilities, and some ethnic minorities (e.g., Roma) are particularly likely to be victims of this

\footnotetext{
1 For example, the World Bank's study of the first decade of transition in the region argued that "positive developments largely explain the rise in inequality [such as] rising returns to education, decompressing wages, and emerging returns to risktaking and entrepreneurship. These forces are welcome despite the increase in inequality, because they signal that the market is now rewarding skills and effort, as in more mature market economies" (World Bank, 2002, p. 14).

2 This can be seen, for example, in the data from the World Bank's ASPIRE database, which show relatively high (compared to other middle-income countries) shares of GDP devoted to social protection, as well as the shares of poorer households receiving pensions and social transfers.

3 UNDP's gender and development and gender inequality indexes show that middle-income countries in Europe and Central Asia generally report less gender inequality than do middle-income countries in other regions (see http://hdr.undp.org/en/data) — when measured, for example, in terms of labor force participation and education attainment).
} 
exclusion. ${ }^{4}$ Public opinion data often point to concerns about large and growing socio-economic inequalities across these transition economies. ${ }^{5} \mathrm{New}$ gender gaps seem to be appearing in a number of countries, reflecting "double burdens" on working women who also provide extensive intra-household care services, as well as (in some countries) declining rates of female labor force participation and education enrolment (for girls). ${ }^{6}$

\section{The "tale of three studies"}

The three studies considered here - the EBRD's “Transition Report 2016-17" (EBRD, 2017); the World Bank's 2018 study "Toward a new social contract: Taking on distributional tensions in Europe and Central Asia" (Bussolo et al., 2018); and UNDP's “Regional human development report 2016. Progress at risk: Inequalities and human development in Eastern Europe, Turkey, and Central Asia" (UNDP, 2016) — seek to connect global inequality narratives with the region's post-communist characteristics. As such, they share a number of commonalities - particularly a reliance on official (national statistical office) data on the distribution of household incomes, as well as the proposition that inequalities are high, rising, or otherwise important and should be addressed. On the other hand, the three studies may be differentiated according to the following criteria.

Conceptual framework. The EBRD report considers inequalities against the backdrops of transitions to market economies, financial inclusion, and convergence of incomes/living standards in less wealthy European countries towards those reported in more wealthy countries. The UNDP report focuses on inequalities as they pertain to the Sustainable Development Goals ${ }^{7}$ — particularly SDGs 10 ("reduce inequalities within and between countries") and 5 ("achieve gender equality and empower women and girls"), and some of the issues associated with the targets and indicators for these goals. The World Bank report examines inequality questions in the region under its "shared prosperity" rubric, as well as from a "social contract" perspective - according to which a stable social contract uses public policies to align market-generated income distributions with societal preferences for equity.

Report objectives. The World Bank report looks to extend inequality narratives developed for the upper-income countries - most of which are parliamentary democracies, have relatively extensive databases on inequalities of wealth (as well as income), and possess progressive income tax and well developed social protection systems - to the middle-income transition economies of Central and Eastern Europe, Turkey, and the Caspian Basin/Central Asia. For much of this latter group, institutions of parliamentary democracy, progressive income tax

\footnotetext{
4 This can be seen in the numbers of people working (or shares of total employment) in subsistence agriculture (i.e., sole proprietorships working on small holdings) or in sectors where average wages are close to the poverty line. For more on Roma labor market and social exclusion, see Robayo and Millan (2019).

5 In addition to the data to this effect presented in the UNDP (2016) and EBRD (2017) reports, other sources with the same results include the World Values Survey and Transparency International corruption perceptions index.

6 World Bank data show women's labor force participation rates falling in the last decade for Kyrgyzstan and Tajikistan. Gender parity rates (showing the ratio of women to men) in tertiary education enrollments during the past decade dropped for Georgia, Ukraine, and Uzbekistan.

7 See https://sustainabledevelopment.un.org/sdgs
} 
systems, and official data on inequalities of wealth are either weaker or absent. Likewise, the "social contract" notion arguably means something rather different (less related to political democracy) in many of these countries, as compared to the West European countries to which the concept's roots can be traced.

In its focus on linkages between inequalities and the SDGs, the UNDP report highlights the opportunities (and limitations) of using the SDGs (particularly when combined with official household survey data) to support analyses and narratives inequality concerning inequalities in the region. This reflects the UNDP report's objective of operationalizing the "leave no one behind" principle that underpins the global Agenda 2030 for sustainable development ${ }^{8}$ (for which the SDGs are the monitoring framework), and to extend these linkages beyond SDGs 5 and 10 to goals 8 (on inclusive growth and decent jobs) and 16 (on inclusive and accountable governance). It also reflects the facts that:

- Such common measures of inequalities as Gini coefficients and Palma ratios are not included in the global SDG indicator set (so that many SDG10 indicators cannot be monitored on basis of publicly available national statistical data);

- Official income distribution data in many of these countries do not show particularly high or rising levels of inequality;

- Different national and international data sets for income distribution in these countries often show different trends that complicate international comparisons and confuse narratives;

- There are virtually no official data on the distribution of wealth in these countries; and

- Subjective (unofficial) data indicate that survey respondents in the region often perceive of inequalities to be significant, growing, and problematic.

In line with its narratives linking inclusion (and sustainability) to economic transition, the EBRD report combines a general overview of inequality issues in transition economies with an analysis of subjective inequality data collected in the EBRD's life in transition (LITS) survey data set. These data, which are based on information collected from some thousands of survey respondents across the region, ${ }^{9}$ show that popular concerns about inequalities in the region are high and rising, and are not necessarily consistent with the pictures presented by national data on income inequalities.

Country coverage accounts for important difference in the reports' foci and conclusions. Whereas the World Bank study's geographic focus includes all the countries of Europe and Central Asia, the EBRD study examines only the transition economies within this group (including Mongolia), largely leaving the West European/OECD-DAC countries out of the analysis. The UNDP study has the narrowest geographic scope, focusing solely on the countries and territories of Europe and Central Asia that fall into the World Bank's low- and middle-income categories, and are viewed by UNDP as programme (i.e., not donor) countries. The transition economies that joined the European Union (EU) in 2004, 2007, and 2013, as well as the Russian Federation and Mongolia, are therefore outside the scope of the UNDP report. These differences in coverage

\footnotetext{
8 See https://sustainabledevelopment.un.org/sdgs

9 The third phase of the EBRD (2016) survey is based on data collected from 51,000 respondents.
} 
have implications for the reports' recommendations, inter alia concerning such policies as progressive taxes on income and wealth - the effectiveness of which is generally understood to decline with growth in average national per-capita income levels across the region.

Data and indicators used also account for differences in focus, conclusions, and recommendations across the three reports. The UNDP report relies extensively on national data on income inequalities drawn from household budget surveys and, in the Western Balkans, the EU's Statistics on Incomes on Living Conditions. These data are sourced directly from national statistical offices and are reported via Gini coefficients and income distribution deciles and quintiles. (This analysis is supplemented by reference to UNDP inequality indicators like the inequality-adjusted human development index, the gender inequality index, and the gender and development index). No attempt was made to standardize or harmonize the national statistical office data; readers are presented with the "raw" income inequality data as seen by national policy makers. Cases in which national inequality data show conflicting trends (either across national indicators or vis-àvis international measures) are highlighted.

By contrast, the EBRD and World Bank reports draw extensively on international data sets (e.g., POVCALNET) that present internationally standardized/ harmonized measures. While these metrics may aspire to greater methodological quality and consistency, they are less likely to meet with national approbation. Moreover (as mentioned above), the EBRD report is strengthened by analysis drawn from the LITS data, which provide a critical contribution to understanding popular perceptions of inequalities that seem to inform popular and policy discourses in the region. ${ }^{10}$

Proposed policy responses. Differences in the fiscal policy responses proposed by the three reports can largely be explained by differences in country coverage. The EBRD and World Bank reports' emphases on greater reliance on wealth (e.g., inheritance, property) taxes and on progressive income taxes, can be explained in part by the fact that such measures are more likely to be successful in upper-income European countries whose fiscal experience (explicitly and implicitly) informs these reports. By contrast, such considerations are less apparent in the UNDP report, which focuses on low- and middle-income transition economies in which progressive income tax structures are generally seen as generating higher levels of tax evasion and avoidance. Reductions in taxes on labor, higher taxes on carbon/unsustainable natural resource consumption patterns, cuts in fossil fuel subsidies, and greater efforts to reduce illicit financial flows are instead emphasized in the UNDP report. This reflects UNDP's emphasis on policy solutions that can simultaneously address environmental sustainability and "leave no one behind" concerns, as well as greater attention to the global finance for sustainable development agenda.

In terms of social policy responses, the World Bank report takes the closest look at universal basic income schemes, but concludes that such policies are less important than investments in education and labor market flexibility. While the EBRD report likewise emphasizes investments in education, it also calls for more extensive use of conditional cash transfers and better targeting of social

$\overline{10}$ The work by Dávalos et al. (2016) also makes an important contribution in this direction. 
benefits in general. The UNDP report by contrast focuses on integrated, wholeof-government approaches to social insurance, assistance, services, education, employment, and migration. This report's proposed expansion of care services to address gender-based labor market (and related forms of social exclusion) is a reflection of this integrated approach.

\section{Towards a common policy agenda}

Differences aside, the reports share a number of analytical and policy commonalities and recommendations, which generally fall into two areas.

More and better inequality data and indicators are needed. All three reports see the prevailing reliance on official income inequality data as problematic. This particularly concerns household budget survey data (especially in the region's low- and middle-income countries), which are widely seen as under-reporting the "tails" of national income distribution patterns. Experience from the region's upper-income countries points to greater efforts to combine personal income tax data with household budget survey data, in order to improve the accuracy of income inequality data. It also underscores the importance of more accurate property (real estate, land) registers - both for the introduction/expansion of property/wealth taxation, and for the collection of more robust data on the distribution of wealth. Greater reliance (for policy purposes) on data concerning spatial/geographic (in addition to socio-economic) inequalities may also be advisable.

Better data could be combined with more appropriate use of inequality indicators - particularly as concerns the shares of national income devoted to labor and capital. For example, because income from capital/property provides such a small share of total (reported) household income in the region, increases in the share of wages and salaries in household incomes can increase inequalities - particularly if this growth occurs towards the top of the wage scale. And because large shares of capital in the region remain under (or have been returned to) state ownership, increases in the share of national income distributed to capital can increase state revenues and help to fund social protection systems - thereby reducing inequality. Expanded use of multi-dimensional inequality indicators like UNDP's inequality-adjusted human development index, or its gender and development and gender inequality indexes, could also be helpful. (This would also better support monitoring of SDGs 5 and 10.)

Tax reform. All three of the reports call for increasing the de facto progressivity of national tax systems. The EBRD and World Bank reports propose making de jure personal income tax systems more progressive and broadening national tax bases; the UNDP report proposes reductions in payroll/labor tax rates, to reduce informality and labor market exclusion. Because payroll taxes are generally regarded as regressive, reductions in these rates can be seen increasing the tax system's overall de facto progressivity. ${ }^{11}$

\footnotetext{
${ }^{11}$ In order to compensate for possible reductions in government budget revenues, the UNDP report calls for increases in carbon taxes or other levies to internalize negative environmental externalities. Because such taxes are generally regarded as regressive, this proposal can be seen reducing tax systems' overall de facto progressivity.
} 
Conspicuously lacking in these reports are the sorts of flat-tax narratives that were fixtures of tax reform debates in the region during the first decade of the new millennium (at least up until the onset of the global financial crisis in 2008-2009; see, for example, Filer et al., 2019). Nor has the global debate on international tax cooperation (in order, for example, to reduce illicit financial flows) made a significant impact on tax reform discussions in the region. However, demographics in many transition economies are increasingly seen as being on course to undermine traditional mechanisms for financing social insurance (e.g., pension and health) systems (see, for example, Abels et al., 2014). Governments, if they are serious about ensuring adequate funding for social protection while also reducing labor market exclusion due to high payroll tax rates, must increasingly be willing to finance these systems from general budget revenues - which should increasingly be financed by carbon and other taxes on negative externalities.

Other policy reforms to address inequalities, and which find support in these three reports, include:

- Increased investment in national capacities for the collection and analysis of official data that are disaggregated by gender and other vulnerability criteria;

- Increased investment in access to education;

- Efforts to strengthen the implementation/enforcement of anti-discrimination legislation (e.g., to provide for "equal pay for equal work," or to reduce discrimination against ethnic minorities); and

- The more aggressive implementation of market and governance reforms to improve commercial environments for small and medium-sized businesses (particularly in depressed areas).

\section{References}

Abels, M., Arias Diaz, O. S., Eckardt, S., Immervoll, H., Koettl-Brodmann, J., Rudolph, H. P., Schwarz, A. M., \& Zviniene, A. (2014). The inverting pyramid: Pension systems facing demographic challenges in Europe and Central Asia. Washington, DC: World Bank.

Braguinsky, S. (2007). The rise and fall of post-communist oligarchs: Legitimate and illegitimate children of praetorian communism. Unpublished manuscript, SUNY Buffalo.

Bussolo, M., Davalos, M. E., Peragine, V., \& Sundaram, R. (2018). Toward a new social contract: Taking on distributional tensions in Europe and Central Asia. Washington, DC: World Bank.

Dávalos, M. E, Demarchi, G., Santos, I., Kits, B., \& Oral, I. (2016). Voices of Europe and Central Asia: New insights on shared prosperity and jobs. Washington, DC: World Bank.

EBRD (2016). Life in transition: A Decade of measuring transition. London: European Bank for Reconstruction and Development.

EBRD (2017). Transition report 2016-17. London: European Bank for Reconstruction and Development.

Filer, R. K., Hanousek, J., Lichard, T., \& Torosyan, K. (2019). "Flattening” tax evasion? Evidence from the post-communist natural experiment. Economics of Transition and Institutional Change, 27 (1), 223-246. https://doi.org/10.1111/ecot.12189

Guriev, S., \& Rachinsky, A. (2005). The Role of oligarchs in Russian capitalism. Journal of Economic Perspectives, 19 (1), 131-150. https://doi.org/10.1257/0895330053147994

Lopez-Calva, L., \& Lustig, N. (2009). The recent decline of inequality in Latin America: Argentina, Brazil, Mexico and Peru. ECINEQ Working Paper, No. 2009-140, Society for the Study of Economic Inequality.

Milanovic, B. (2016). Global inequality: A new approach for the age of globalization. Cambridge, MA: Harvard University Press. 
Milanovic, B. (2011). The haves and the have-nots. New York: Basic Books.

Milanovic, B. (2012). Global income inequality by the numbers: In history and now - an overview. World Bank Policy Research Working Paper, No. 6259.

OECD (2015). In it together: Why less inequality benefits all. Paris: Organization for Economic Cooperation and Development.

Piketty, T. (2014). Capital in the twenty-first century. Cambridge, MA: Harvard University Press.

Robayo, M., \& Millan, N. (2019). Breaking the cycle of Roma exclusion in the Western Balkans. Washington, DC: World Bank.

Stiglitz, J. (2012). The price of inequality. New York and London: W.W. Norton,

UNDP (2013). Humanity divided: Confronting inequality in developing countries. New York: United Nation Development Program.

UNDP (2016). Regional human development report. Progress at risk: Inequalities and human development in Eastern Europe, Turkey, and Central Asia. Istanbul: United Nation Development Program.

Wilkinson, R., \& Pockett, K. (2010). The spirit level: Why equality is better for everyone. London: Penguin.

World Bank (2002). Transition - The first ten years: Analysis and lessons for Eastern Europe and the former Soviet Union. Washington, DC: World Bank. 